\title{
SPP1 wt Allele
}

National Cancer Institute

\section{Source}

National Cancer Institute. SPP1 wt Allele. NCI Thesaurus. Code C95571.

Human SPP1 wild-type allele is located in the vicinity of $4 \mathrm{q} 22.1$ and is approximately $8 \mathrm{~kb}$ in length. This allele, which encodes osteopontin protein, plays a role in the modulation of both intercellular communication and matrix mineralization. Aberrant expression may be associated with many cancers. 